\title{
Analisis Biaya Transaksi pada Kelembagaan Pertanian Gapoktan Penerima Program Pengembangan Usaha Agribisnis Pedesaan (PUAP) di Desa Raman Aji Kecamatan Raman Utara Kabupaten Lampung Timur
}

\section{Transaction Cost Analysis in Agricultural Institutional Gapoktan Recipient Business Agribusiness Development Program (PUAP) in Raman Aji Village North Raman District East Lampung Regency}

\section{Zulkarnain* dan Windu Mangiring}

Sekolah Tinggi Ilmu Pertanian (STIPER) Dharma Wacana, Kota Metro, Indonesia

${ }^{*}$ E-mail :zulfadhilalzabir@gmail.com

\begin{abstract}
Gapoktan (Combined Farmer Group) is an agricultural institution implementin PUAP program. In the implementation of the PUAP program, transaction costs can not be avoided. Transaction costs become something that is considered normal and activities become commonplace in the process of making contracts and efforts to achieve common goals.This study aims to analyze and study the structure of transaction costs on agricultural institutions Gapoktan recipient PUAP program in East Lampung regency. The location of this research was conducted in Raman Aji Village, North Raman District, East Lampung Regency.Sampling technique used purposive sampling method (purposely) and simple random sampling method (simple random). Respondents in this study were the chairman and members of farmer group receiving PUAP program at Gapoktan Jaya Makmur in Raman Utara District of East Lampung Regency as many as 68 people.To answer the purpose of research used transaction cost analysis (transaction cost). The result of this research is PUAP program aid fund of Rp. 500.000,00 per member Gapoktan got average transaction cost equal to Rp. 203.235.00. The contract security cost is the largest transaction cost when compared with the information cost and the coordination cost which is $58.61 \%$.
\end{abstract}

Keywords: Transaction costs, Institutional, PUAP Program, Gapoktan

Disubmit : 29 September 2017, Diterima : 01 Desember 2017, Disetujui :08 Desember 2017

\section{PENDAHULUAN}

Indonesia merupakan salah satu negara berkembang di dunia yang masih menghadapi permasalahan baik dalam bidang ekonomi, politik, hukum, sosial, budaya dan bidang-bidang lainnya. Beberapa masalah yang belum dapat diselesaikan oleh pemerintah diantaranya adalah masalah pengentasan kemiskinan dan pengangguran. Tingginya angka kemiskinan per tahun di Indonesia menjadikan kemiskinan sebagai masalah pokok nasional yang penanggulangannya menjadi prioritas utama dalam pelaksanaan pembangunan kesejahteraan sosial sehingga akan mempengaruhi perekonomian nasional (Suroso, 2013)

Kemiskinan di Indonesia ditandai oleh rendahnya mutu kehidupan masyarakat, hal ini dapat ditunjukkan oleh Indeks Pembangunan Manusia (IPM) Indonesia yang dirilis United Nations Development Program (UNDP). Indeks Pembangunan Manusia (IPM) menunjukkan kualitas manusia Indonesia pada 
Tahun 2013 berada pada level 0,629 yang menempatkan Indonesia pada posisi ke lima jika dibandingkan negara di kawasan Asia Tenggara (ASEAN) (https://id.wikipedia.org/wiki/Indeks_Pembangunan_Manusia). Hasil yang cukup mencengangkan mengingat Indonesia adalah negara besar dilihat dari luas wilayah dan jumlah penduduk. Berdasarkan data BPS Tahun 2015, jumlah penduduk miskin di Indonesia pada bulan September 2015 sebesar 28,59 juta orang dan sebanyak 59,79 persen penduduk miskin tersebut berada di daerah perdesaan yang pada umumnya bekerja pada subsektor pertanian tanaman pangan dan perikanan (nelayan). Kemiskinan di pedesaan disebabkan oleh adanya ketimpangan pembangunan antara desa sebagai produsen pertanian dan kota sebagai pusat kegiatan ekonomi.

Dalam rangka penanggulangan kemiskinan di pedesaan, pemerintah mengeluarkan kebijakan dan menggalakkan program-program revitalisasi dan pemberdayaan. Pada tanggal 11 Juni 2005 Presiden RI telah mencanangkan Revitalisasi Pertanian, Perikanan, dan Kehutanan (RPPK) sebagai salah satu dari Triple Track Strategy dari Kabinet Indonesia bersatu dalam rangka pengurangan kemiskinan dan pengangguran serta peningkatan daya saing ekonomi nasional dan menjaga kelestarian sumber daya pertanian, perikanan dan kehutanan.

Menindak lanjuti kebijakan-kebijakan pemerintah, Departemen Pertanian melalui Keputusan Menteri Pertanian (KEPMENTAN) Nomor 545/Kpts/OT.160/9/2007 membentuk Tim Pengembangan Usaha Agribisnis Perdesaan (PUAP) serta diterbitkannya Peraturan Menteri Pertanian Nomor 16/permentan/OT.140/2/2008 pada tanggal 11 Februari 2008 tentang Juknis Program PUAP. Program PUAP berbentuk fasilitasi bantuan modal usaha petani anggota baik petani pemilik, petani penggarap, buruh tani maupun rumah tangga tani yang disalurkan melalui Gabungan Kelompok Tani (Gapoktan) selaku kelembagaan pertanian di Desa. Program Pengembangan Usaha Agribisnis Pertanian (PUAP) dimulai sejak tahun 2008. Dana Bantuan Langsung Masyarakat (BLM) program PUAP telah disalurkan sebagian besar kepada Gapoktan-Gapoktan dengan nilai Rp 1,0573 trilyun dengan jumlah rumah tangga petani yang terlibat adalah sekitar 1,32 juta. Berdasarkan kebijakan teknis program PUAP, sebaran lokasi PUAP meliputi 33 propinsi, 379 kabupaten atau kota, 1.834 kecamatan miskin dan 10.524 desa miskin.

Posisi kelembagaan dirancang untuk mengurangi biaya transaksi dalam pasar yang kompetitif (Furubotn dan Rudolf, 2005). Pada kenyataannya, biaya transaksi tidak dapat dihilangkan tetapi dapat diminimalkan. Minimalisasi biaya transaksi memiliki arti penting tetapi meminimalisasi biaya transaksi bukanlah suatu tujuan melainkan sebuah proses untuk mencapai tujuan yang lebih luas dan maksimalisasi kesejahteraan masyarakat. Selain itu, biaya transaksi akan selalu positif dan ada dimana-mana (Allen, 2005). Sejalan dengan perkembangan ilmu mengenai ekonomi kelembagaan, kelembagaan pertanian Gapoktan penerima Program PUAP pun diduga tidak akan luput dari adanya biaya transaksi. Dalam konteks kelembagaan pertanian Gapoktan, biaya transaksi didekatkan dengan prinsip menjalankan organisasi untuk mendukung program PUAP diantaranya yaitu (1) biaya pencarian informasi (Information cost); (2) biaya koordinasi (Coordination cost); (3) biaya pengamanan kontrak (Controlling cost). Biaya-biaya ini menjadi suatu hal yang dianggap normal, pada saat segala bentuk penyelewengan dan aktivitas menjadi hal yang lazim dalam proses pembuatan kontrak dan usaha pencapaian tujuan bersama.

Berdasarkan uraian diatas, rumusan masalah pada penelitian sebagai berikut "Bagaimana struktur biaya transaksi pada kelembagaan pertaniaan Gapoktan penerima program PUAP di Kabupaten Lampung Timur". Adapun tujuan penelitian ini adalah : "Menganalisis dan mempelajari struktur biaya transaksi pada kelembagaan pertanian Gapoktan penerima program PUAP di Desa Rama Aji Kecamatan Raman Utara Kabupaten Lampung Timur"

\section{METODE PENELITIAN}

Lokasi dan Waktu Penelitian. Lokasi penelitian ini dipilih secara sengaja (purposive) yang berada pada Gapoktan Jaya Makmur Desa Raman Aji Kecamatan Raman Utara Kabupaten Lampung Timur. 
Dengan alokasi waktu mulai dari bulan Februari sampai dengan bulan Juni 2017. Adapun alasan penentuan lokasi tersebut berdasarkan pertimbangan sebagai berikut : (1) Gapoktan berada di wilayah Kabupaten Lampung Timur yang sedang dan telah mendapatkan dana Bantuan Langsung Masyarakat (BLM) PUAP secara bergulir pada tiap-tiap kelompok tani dimulai dari Tahun pertama program PUAP Tahun 2008, (2) Gapoktan tersebut merupakan binaan dari Badan Pelaksana Penyuluhan Pertanian Peternakan dan Kehutanan (BP4K) Kabupaten Lampung Timur, dan (3) Mendapatkan piagam penghargaan dari Bupati Kabupaten Lampung Timur atas prestasinya dalam pengembangan dana PUAP Kabupaten Lampung Timur.

Populasi dan Teknik Pengambilan Sampel. Populasi dalam penelitian ini adalah anggota kelompok tani penerima program PUAP pada Gapoktan Jaya Makmur sebanyak 568 orang. Teknik Pengambilan sampel didapatkan berdasarkan perhitungan (Sugiarto $d k k$., 2003), dengan metode pengambilan sampel secara acak sederhana (simple random sampling) dan sengaja (purposive sampling). Berdasarkan perhitungan, sampel yang didapat sejumlah 68. Proporsi untuk sampel dari masing-masing populasi anggota kelompok tani merujuk pada Nasir (1988 dalam zulkarnain, 2010)

Metode, Jenis Data dan Teknik Pengumpulan Data. Metode pengambilan sampel akan dilakukan dengan menggunakan dua metode yang berbeda yaitu metode purposive sampling (sengaja) dan metode simple random sampling (acak sederhana). Perwakilan sampel pertama diambil menggunakan metode purposive yakni ketua kelompok tani. Pemilihan ketua kelompok tani dengan pertimbangan bahwa ketua kelompok tani memiliki informasi yang lebih banyak seputar implementasi dan alokasi pemanfaatan bantuan Program PUAP, serta dapat memberikan informasi pendukung lainnya yang lebih jelas lagi untuk penelitian ini. Perwakilan sampel yang ke dua ditentukan dengan menggunakan metode simple random. Pengambilan sampel ditujukan kepada anggota kelompok tani penerima dana PUAP dengan cara pengundian (Tabel.1).

Tabel 1. Nama kelompok tani, jumlah anggota kelompok tani dan jumlah sampel pada Gapoktan Jaya Makmur Desa Raman Aji Kecamatan Raman Utara Kabupaten Lampung Timur, 2015.

\begin{tabular}{clcc}
\hline No. & \multicolumn{1}{c}{ Nama Kelompok Tani } & Jumlah Anggota Kelompok Tani & Jumlah Sampel \\
\hline 1 & Subur Jaya & 29 & 3 \\
2 & Tani Jaya & 38 & 4 \\
3 & Yoso Makmur & 30 & 4 \\
4 & Usaha Tani & 30 & 4 \\
5 & Usaha Tani I & 28 & 3 \\
6 & Usaha Tani II & 21 & 2 \\
7 & Usaha Tani III & 26 & 3 \\
8 & Sido Makmur & 30 & 4 \\
9 & Sediyo Maju & 30 & 4 \\
10 & Sampurna II & 23 & 3 \\
11 & Rasa Sampurna & 26 & 3 \\
12 & Mekar Jaya & 30 & 4 \\
13 & Maju Lestari & 23 & 3 \\
14 & Tani Maju & 30 & 4 \\
15 & Rukun Tani & 30 & 4 \\
16 & Sri Tani & 22 & 2 \\
17 & Al Amin & 27 & 3 \\
18 & Tunas Tani & 30 & 4 \\
19 & Sido Muncul & 27 & 3 \\
20 & Sido Maju & 38 & 4 \\
\hline
\end{tabular}

Sumber : BP4K Kab. Lampung Timur, 2015 
Penelitian ini menggunakan beberapa data, yaitu : (1) data Primer adalah data yang di dapatkan dari hasil wawancara atau observasi secara langsung pada gapoktan serta kelompok tani di Desa Raman Aji Kecamatan Raman Utara Kabupaten Lampung Timur, (2) data Sekunder adalah data yang diperoleh dari dokumen yang dimiliki oleh kelompok tani yang berkaitan dengan obyek penelitian, lembaga terkait/instansi terkait, laporan-laporan, publikasi dan pustaka lainnya yang berhubungan dengan penelitian ini. Dalam pengumpulan data yang lengkap guna menyusun penelitian ini digunakan instrumen-instrumen penelitian seperti (1) Interview (Wawancara), (2) observasi (Pengamatan Langsung), (3) dokumentasi, dan (4) kuesioner

Analisis Data. Dalam penelitian ini untuk menghitung biaya transaksi pada Gapoktan penerima program PUAP digunakan rumus sebagai berikut:

$$
\mathrm{TC}=\mathrm{X}_{1}+\mathrm{X}_{2}+\mathrm{X}_{3}
$$

Keterangan :

$\begin{array}{lllllllll}\mathrm{TC} & : & \text { biaya transaksi (Transaction cost) } & (\mathrm{Rp} .) & \mathrm{X}_{2} & : & \text { biaya koordinasi (Coordination cost) } & (\mathrm{Rp} .) \\ \mathrm{X}_{1} & : & \text { biaya informasi (Information cost) } & (\mathrm{Rp} .) & \mathrm{X}_{3} & : \text { biaya pengamanan } & \text { (Controlling cost) }\end{array}$

Pada penelitian ini, biaya transaksi didekatkan dengan prinsip menjalankan organisasi/kelembagaan Gapoktan Jaya Makmur untuk mendukung kegiatan program PUAP yaitu sebagai berikut :

Secara matematika, biaya informasi dapat ditulis sebagai berikut:

Keterangan :

$$
\mathrm{X}_{1}=\mathrm{X}_{11}+\mathrm{X}_{12}+\mathrm{X}_{13}
$$

$\mathrm{X}_{1}: \mathrm{b}$

iaya informasi

(Rp.)

$\mathrm{X}_{11}$ : biaya pengadaan program

$\mathrm{X}_{12}$ : biaya awal mulanya terbentuknya kelompok tani untuk kemudian menjadi gapoktan penerima program PUAP

$\mathrm{X}_{13}$ : biaya pertemuan agar petani menjadi Penerima Program PUAP

Secara matematika, biaya koordinasi dapat ditulis sebagai berikut :

Keterangan :

\begin{tabular}{|c|c|c|c|c|}
\hline $\mathrm{X}_{2}$ & biaya koordinasi ................................... & (Rp.) & $\mathrm{X}_{23}$ & 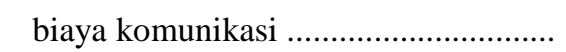 \\
\hline$X_{21}$ & 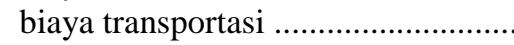 & (Rp.) & $\mathrm{X}_{24}$ & biaya administrasi . \\
\hline $\mathrm{X}_{22}$ & biaya pertemuan …………….................. & (Rp.) & $\mathrm{X}_{25}$ & biaya pendapatan yang hilang. \\
\hline
\end{tabular}

$$
X_{2}=X_{21}+X_{22}+X_{23}+X_{24}+X_{25}
$$

Secara matematika, biaya pengamanan kontrak dapat ditulis sebagai berikut :

$$
\mathrm{X}_{3}=\mathrm{X}_{31}+\mathrm{X}_{32}+\mathrm{X}_{33}
$$

Keterangan :

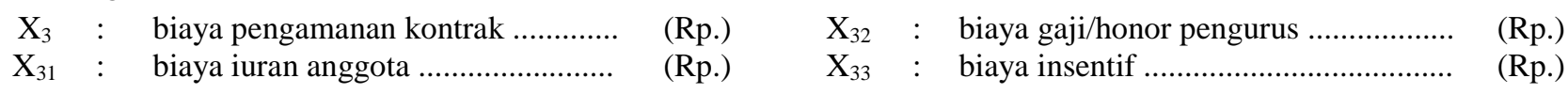




\section{HASIL DAN PEMBAHASAN}

Biaya Transaksi. Teori biaya transaksi berasal dari pendekatan kelembagaan ekonomi baru dan berfokus pada tata kelola kelembagaan. Menurut Williamson (1986), ekonomi biaya transaksi berlainan dengan ekonomi neoklasikal. Ekonomi neoklasik menganggap dalam aktivitas ekonomi tidak mengalami hambatan yang berarti karena mempunyai informasi yang sempurna. Keadaan sebenarnya adalah pada setiap proses pertukaran ekonomi seperti dalam jual beli (economic exchange), terdapat hambatan yang dapat disebut biaya transaksi. Hubungan keterkaitan biaya transaksi (cost transaction) dengan kelembagaan mempunyai makna strategis sebagai indikator tingkat efisiensi kelembagaan. Indikator efisiensi kelembagaan diamati dari tinggi rendahnya biaya transaksi yang muncul dari kegiatan transaksi ekonomi. Semakin rendah biaya transaksi menunjukkan kelembagaan yang efisien, demikian sebaliknya Yeager (1999 dalam Yustika, 2006). Biaya transaksi tersebut bisa didefinisikan sebagai ongkos yang muncul untuk mencari informasi, melakukan koordinasi, membuat kontrak, dan menegakkannya (law enforcement). Biaya transaksi tampak memiliki bentuk yang beragam, yang hampir selalu disebabkan oleh ketidakpastian dan/atau informasi asimetris (Rahman, 2011)

Biaya transaksi dalam penelitian ini dibedakan menjadi tiga yaitu biaya informasi, biaya koordinasi dan biaya pengamanan kontrak. Perhitungan biaya transaksi ini difokuskan pada kegiatan kelembagaan pertanian yang dilakukan di Desa Raman Aji Kecamatan Raman Utara, dalam hal ini Gapoktan Jaya Makmur penerima Program PUAP (Pengembangan Usaha Agribisnis Pedesaan).

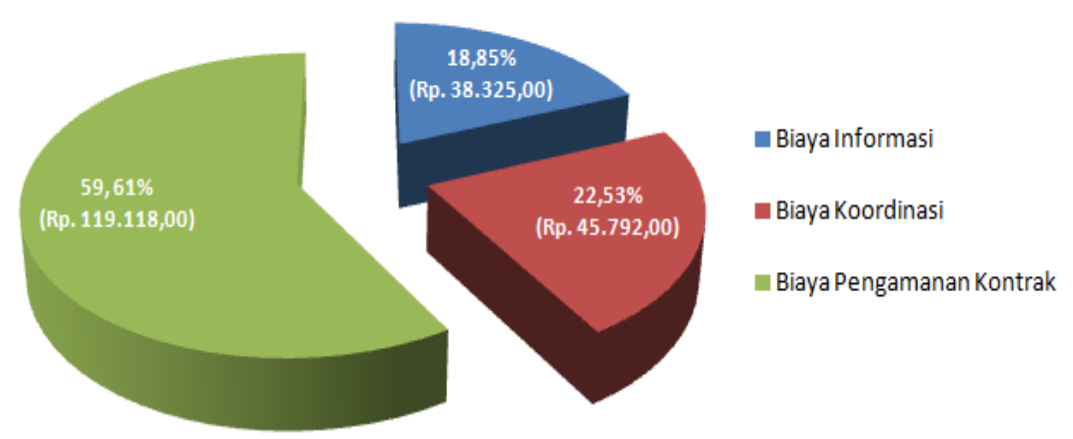

Gambar 1. Biaya Transaksi pada Kelembagaan Pertanian Gapoktan Jaya Makmur Penerima Program PUAP

Berdasarkan Gambar 1 menunjukkan bahwa rata-rata biaya transaksi per anggota dalam penerimaan Program PUAP sebesar Rp. 203.235,00. Biaya pengamanan kontrak merupakan jenis biaya transaksi yang terbesar jika dibandingkan dengan biaya informasi maupun biaya koordinasi sebesar 58,61 \%. Penyaluran dana Program PUAP kepada anggota Gapoktan sebesar Rp. 500.000,00, setelah adanya biaya transaksi maka dana bantuan program PUAP yang diterima menjadi Rp. 296.765,00 atau 59,35 \%. Dengan adanya biaya transaksi maka dana program PUAP yang diperoleh oleh anggota Gapoktan tanpa disadari tidak sesuai dengan yang dikontrak. Biaya transaksi tersebut akan mengurangi bantuan modal petani yang didapatkan dari program PUAP sehingga petani akan terkendala dalam berusahatani atau usaha.

Adapun biaya transaksi dalam penerima program PUAP (Pengembangan Usaha Agribisnis Pedesaan) di Gapoktan Jaya Makmur adalah sebagai berikut :

Biaya informasi. Biaya informasi dapat bersifat awal sebelum kegiatan dilakukan atau dilaksanakan, hanya sebatas mencari kepastian (Suciatia $d k k$., 2014). Informasi yang dibutuhkan untuk merumuskan atau membuat kebijakan terkait dengan tindakan yang akan dilakukan, sehingga tindakan atau aktivitas yang diambil sesuai dengan kebutuhan dan tujuan yang diharapkan. Informasi yang dibutuhkan bukan hanya oleh individu dan kelompok dalam masyarakat, akan tetapi oleh semua jenis organisasi termaksud kelembagaan kelompok tani. Tujuan kelompok tersebut adalah berbagi informasi, maka di dalam berkomunikasi yang 
dilakukan untuk menanamkan pengetahuan (to impart knowledge) dan menambahkan informasi yang dapat dijadikan sebagai pengambilan keputusan anggota kelompok tani. Kakansing (2009 dalam Rintjap, 2015) menyatakan bahwa petani pada dasarnya melakukan aktifitas untuk memenuhi kebutuhannya.

Pentingnya biaya transaksi yang diutarakan oleh North (1990 dalam Yustika, 2006) bahwa biaya mencari informasi merupakan kunci dari biaya transaksi. Salah satu biaya transaksi yaitu biaya informasi, dimana biaya informasi merupakan biaya yang terdiri dari biaya pengadaan program, biaya pembentukan Koptan menjadi anggota Gapoktan Penerima Program PUAP, dan biaya pertemuan anggota Koptan agar menjadi penerima Program PUAP.

Tabel 2. Biaya Informasi pada Kelembagaan Pertanian Gapoktan Jaya Makmur Penerima Program PUAP

\begin{tabular}{|c|c|c|c|}
\hline \multicolumn{2}{|c|}{ Jenis Biaya Transaksi } & Biaya Transaksi & Persentase (\%) \\
\hline \multicolumn{4}{|c|}{ Biaya Informasi } \\
\hline A. & Biaya pengadaan program & 16.838 & 8,28 \\
\hline B. & $\begin{array}{l}\text { Biaya awal mula terbentuknya kelompok tani menjadi } \\
\text { anggota Gapoktan Penerima Program PUAP }\end{array}$ & 1.471 & 0,72 \\
\hline C. & $\begin{array}{l}\text { Biaya pertemuan agar petani menjadi Penerima Program } \\
\text { PUAP }\end{array}$ & 20.016 & 9,85 \\
\hline Sub Tot & & 38.325 & 18,86 \\
\hline
\end{tabular}

Sumber : Data Primer (diolah), 2017

Tabel 2 menunjukkan bahwa biaya informasi yang terbesar adalah biaya pertemuan anggota koptan agar menjadi penerima Program PUAP. Biaya yang dikeluarkan berupa pertemuan untuk membahas Program PUAP. Pertemuan tersebut dilakukan tiga tahapan yaitu pertemuan membahas kesiapan kelompok tani, pertemuan membahas proses pembuatan RUA (Rencana Usaha Anggota), RUK (Rencana Usaha Kelompok) dan RUB (Rencana Usaha Bersama), dan pertemuan membahas pencairan dana. Dalam pertemuan tersebut, biaya yang dikeluarkan oleh anggota Gapoktan berupa minuman, snack (makanan ringan), bahan bakar, dan rokok.

Biaya informasi yang dikeluarkan oleh anggota Gapoktan sebesar Rp. 38.325,00 atau 18,86 \% dari total biaya transaksi sebesar Rp. 203.235. Biaya informasi berkaitan dengan ketidaklengkapan informasi pada situasi di mana seluruh pihak yang melakukan transaksi menghadapi level informasi sama tetapi tidak lengkap. Akibat kekurangan informasi inilah yang menimbulkan tambahan biaya transaksi (Rahman, 2011). Pentingnya biaya transaksi dikemukakan oleh North (1990 dalam Yustika, 2006) menyatakan bahwa biaya mencari informasi merupakan kunci dari biaya transaksi, yang terdiri atas biaya untuk mengerjakan pengukuran kelengkapan-kelengkapan (attributes) yang dipertukarkan dan ongkos untuk melindungi hak-hak kepemilikan (property rights) dan menegakkan kesepakatan (enforcing agreements). Sehingga satu pihak sangat mungkin memiliki informasi yang lebih, dibandingkan pihak lain. Kemudian inilah yang menimbulkan adanya biaya transaksi (Setyanti, 2016).

Kelompok yang terdiri dari individu-individu memiliki keterbatasan kemampuan untuk memproses dan menggunakan informasi yang tersedia, sedangkan informasi yang tersedia sangatlah banyak dan kompleks (Setyanti, 2016). Pengaturan aturan kelompok yang bisa mendorong rasa memiliki, tanggung jawab, dan partisipasi bisa ditegakkan, sehingga pada saat pertemuan, naik turunnya antusiasme dan hubungan sosial yang baik kohesivitas masyarakat di tingkat lokal bisa terjaga. Pertemuan kelompok bisa berupa tindakan kolektif masyarakat seperti arisan, yasinan dan gotong royong telah memainkan peran penting dalam menjaga semangat antar anggota kelompok (Arifin, 2006). Hal tersebut yang dilakukan oleh Gapoktan Jaya Makmur untuk mengumpulkan anggotanya dalam pertemuan.

Biaya informasi masih didominasi oleh biaya pertemuan agar petani menjadi penerima Program PUAP sebesar Rp. 20.016,00. Biaya pertemuan yang dikeluarkan oleh anggota Gapoktan penerima Program PUAP 
antara lain minuman/makanan, bahan bakar dan rokok. Dari ketiga sumber biaya pertemuan, biaya rokok yang paling besar dan hampir keseluruhan anggota Gapoktan berjenis kelamin laki-laki. Menurut Nasrul (2012), adanya kelompok tani dapat menjadi konsolidasi petani dalam satu wadah untuk menyatukan gerak ekonomi dari pra produksi hingga pemasaran. Pertemuan yang dilakukan oleh kelompok tani tidak sebatas mengenai program PUAP tetapi hal-hal yang berkaitan dengan kegiatan agribisnis mulai dari pengadaan saprodi, budidaya sampai pascapanen.

Biaya pengadaan program sebesar Rp. 16.838,00 seperti mengadakan pertemuan pengurus Gapoktan dengan pihak BPP (Balai Penyuluhan Pertanian), serta melakukan pelatihan pengurus Gapoktan (ketua, sekretaris, dan bendahara) selama 7 (tujuh) hari. Pelatihan tersebut untuk membantu pengurus Gapoktan dalam mengajukan program PUAP. Program PUAP yang diberikan berupa bantuan pendanaan kepada petani agar petani terbantukan dalam melakukan usahataninya dan dana yang diberikan ini berupa pinjaman untuk dikembangkan, dimana dana tersebut diberikan kepada petani dengan syarat yang mudah (Sagala, 2010). Pentingnya program PUAP untuk pengembangan usaha petani, maka perlu adanya pertemuan pihak-pihak terkait dalam hal ini adalah Gapoktan dan BPP. Pertemuan tersebut membicarakan prosedur dan persyaratan yang harus disiapkan untuk pengajuan program PUAP. Kemudian, pengurus Gapoktan mengikuti pelatihan guna mempermudah dalam proses pengajuan Program PUAP.

Biaya awal mula terbentuknya kelompok tani menjadi anggota Gapoktan Penerima Program PUAP yang paling sedikit dikeluarkan yaitu sebesar Rp. 1.471, 00. Pihak Gapoktan (Gabungan Kelompok Tani) mengajak seluruh kelompok tani untuk membicarakan program-program pemerintah, salah satu program PUAP. Pihak Gapoktan menekankan bahwa program PUAP memberikan manfaat untuk meningkatkan usahanya. Sealin itu, program PUAP merupakan bantuan dana dari pemerintah yang nantinya ada evaluasi dari pemerintah bagi Gapoktan. Pengurus Gapoktan akan melakukan evaluasi bagi anggota Gapoktan penerima PUAP, hal ini sejalan dengan penelitian Nursyamsiah (2010 dalam Wijianto, 2012) yang menyatakan bahwa pengurus Gapoktan tidak akan memberikan pinjaman tahap kedua apabila ada riwayat peminjam yang sulit mengembalikan pinjaman dana PUAP.

Biaya Koordinasi. Menurut Moekijat (1994 dalam Anggraeni, 2014) koordinasi merupakan sebagai penyelarasan kegiatan-kegiatan yang saling bergantung dari individu, kelompok atau organisasi yang dilakukan secara teratur guna mencapai tujuan bersama. Dalam koordinasi yang efektif memiliki syarat, salah satunya melalui komunikasi yang efektif dan tukar menukar informasi secara terus menerus sehingga perbedaan-perbedaan antar individu dapat diatasi dan akan membawa perubahan-perubahan kebijakan maupun program untuk masa mendatang.

Tabel 3. Biaya koordinasi pada Kelembagaan Pertanian Gapoktan Jaya Makmur Penerima Program PUAP

\begin{tabular}{|c|c|c|c|}
\hline \multicolumn{2}{|c|}{ Jenis Biaya Transaksi } & Biaya Transaksi & Persentase (\%) \\
\hline \multicolumn{4}{|c|}{ Biaya Informasi } \\
\hline A & Biaya Transportasi & 4.421 & 2,175 \\
\hline B & Biaya Pertemuan & 4.575 & 2,25 \\
\hline $\mathrm{C}$ & Biaya Komunikasi & 1.448 & 0,71 \\
\hline $\mathrm{D}$ & Biaya Administrasi & 13.654 & 6,72 \\
\hline $\mathrm{E}$ & Biaya Pendapatan Yang Hilang & 21.703 & 10,68 \\
\hline \multicolumn{2}{|c|}{ Sub Total } & 45.792 & 22,53 \\
\hline \multicolumn{2}{|c|}{ Total Biaya Transaksi } & \multicolumn{2}{|c|}{$203.235(40,65 \%)$} \\
\hline
\end{tabular}

Sumber : Data Primer (diolah), 2017

Koordinasi yang melalui konsensus dapat menjadi motivasi untuk kepentingan bersama yang saling membutuhkan atau membantu dengan melalui ide. Selain itu koordinasi melalui pedoman kerja menyangkut tugas, wewenang, tata kerja serta prosedur kerja agar terdapat kesatuan gerak dan kesatuan tindakan yang tertuang dalam petunjuk atau pedoman (Akmal, 2006). Menurut (Arifin, 2006) biaya koordinasi untuk 
menjalankan kelompok sebagai organisasi atau kelembagaan yang solid tidak murah, hal tersebut bisa ditemukan di mana saja sesuai dengan tempat keberadaan kelembagaan atau organisasi.

Tabel 3 menunjukkan bahwa biaya koordinasi yang terbesar adalah biaya pendapatan yang hilang. Biaya yang dikeluarkan anggota Gapoktan yang berupa pengantian akibat dari meninggalkan pekerjaannya. Hampir seluruh anggota Gapoktan merupakan petani sehingga pekerjaannya berhubungan dengan bidang pertanian. Dalam pertemuan, anggota Gapoktan berusaha hadir untuk mengetahui proses dan persyaratan program PUAP, sehingga anggota Gapoktan dapat mempersiapkan hal-hal yang dibutuhkan pada saat pengajuan dana bantuan dari program PUAP. Program PUAP sangat membantu petani dalam pengadaan saprodi atau input pertanian sehingga dapat meningkatkan pendapatan.

Biaya koordinasi masih didominasi oleh biaya pendapatan yang hilang sebesar Rp. 21.703,00 atau $10,68 \%$ dari total biaya transaksi sebesar Rp. 203.235,00. Biaya pendapatan yang hilang dikeluarkan anggota Gapoktan yang berupa pengantian akibat dari meningalkan pekerjaannya untuk melakukan pertemuan atau rapat membahas tentang program PUAP. Komponen biaya koordinasi yang lainnya yaitu biaya administrasi. Biaya administrasi tersebut berkaitan dengan dokumen pengajuan program PUAP, halhal yang dibutuhkan buku tulis, fotocopy dokumen, materai dan alat-alat tulis. Besarnya biaya admintrasi yang dikeluarkan sebesar Rp.13.654,00 atau 6,72 \% dari total biaya transaksi Rp. 203.235,00. Administrasi yang dilaksanakan secara teratur dan diatur maka dapat mencapai tujuan yang diharapkan. Adminsitrasi yang teratur dilihat dari kegiatan perencanaan, pelaksanaan, dan pengawasan tersebut harus dilakukan secara terus-menerus dan berkelanjutan sedangkan administrasi yang diatur maksudnya seluruh kegiatan harus disusun, disesuaikan satu sama lainnya supaya terdapat keseimbangan tugas antara yang satu dengan yang lain.

Biaya administrasi yang lebih besar penggunaannya adalah pembelian buku tulis, buku tulis tersebut dipergunakan untuk pencatatan mengenai data anggota Poktan/Gapoktan, pencairan dana bantuan Program PUAP, laporan keuangan Gapoktan dan pengembangan Program PUAP. Buku tersebut dibuat khusus supaya pada saat data yang dibutuhkan tidak mengalami kesulitan dalam mencarinya sehingga pada saat pelaporan pengembangan dana PUAP, Gapoktan sudah mempunyai data lengkap yang tersusun rapih. Dalam menjalankan organisasi/kelembagaan, pertemuan merupakan bagian yang tidak bisa ditinggalkan sehingga biaya pertemuan digunakan untuk mempertahankan soliditas organisasi/kelembagaan. Pertemuan merupakan kesempatan yang tidak bisa diabaikan di antara anggota kelompok untuk menghadirin pertemuan kelompok, karena petani bisa kehilangan waktu dan pendapatan pada hari itu. Besarnya biaya pertemuan pada saat koordinasi yang dikeluarkan sebesar Rp.4.575,00 atau 2,25 \% dari total biaya transaksi Rp. 203.235,00. Pertemuan yang dilakukan satu kali pada waktu akhir musim tanam. Pertemuan tersebut membahas usahatani yang dilakukan oleh petani penerima PUAP seperti kendala-kendala dalam berusahatani, selain itu membahas dana PUAP yang telah dipergunakan.

Beberapa anggota Gapoktan harus mengeluarkan biaya transportasi yang berupa pembelian bahan bakar. Menurut Utomo (2010 dalam Setiani, 2015) transportasi merupakan perpindahan penumpang atau orang dari suatu tempat ketempat lain atau tujuan yang dibutuhkan. Transportasi yang dipergunakan untuk menghadiri pertemuan atau rapat Gapoktan adalah sepeda motor. Hampir seluruh anggota Gapoktan bertempat tinggal didaerah yang sedikit jauh dari tempat sekretariatan Gapoktan Jaya Makmur. Besarnya biaya transportasi pada saat koordinasi yang dikeluarkan sebesar Rp.4.412,00 atau 2,17 \% dari total biaya transaksi Rp. 203.235,00. Biasanya, banyak petani dengan senang hati bersedia berpartisipasi dalam pertemuan tersebut, tidak hanya untuk bersosialisasi dan berbagi pengetahuan bahkan pemecahan masalah tetapi berharap bisa mendapatkan lebih banyak informasi langsung dari Gapoktan yang merupakan wadah petani.

Dalam memperlancar koordinasi pengurus dan anggota Gapoktan, maka diperlukan biaya komunikasi. Komunikasi bertujuan untuk mengumpulkan orang yang mempunyai tujuan bersama untuk berinteraksi satu 
sama lain sebagai bagian dari kelompok (Mulyana, 2005). Biaya komunikasi yang dibutuhkan berupa biaya menelepon maupun biaya pesan singkat (sms), hal tersebut sering digunakan oleh anggota Gapoktan untuk mempermudah menyampaikan informasi pertemuan atau rapat sehingga anggota Gapoktan akan mengetahui jadwal maupun agenda yang akan dibahas. Besarnya biaya komunikasi pada saat koordinasi yang dikeluarkan sebesar Rp.1.448,00 atau 0,71 \% dari total biaya transaksi Rp. 203.235,00. Biaya komunikasi tersebut paling sedikit dikeluarkan pada saat koordinasi.

Biaya Pengamanan Kontrak. Keterkaitan biaya transaksi dengan kelembagaan mempunyai makna strategis sebagai indikator tingkat efisiensi. Salah satu biaya transaksi yang besar pengeluarannya adalah biaya pengamanan kontrak. Indikator efisiensi suatu kelembagaan dapat dilihat dari tinggi rendahnya biaya transaksi yang muncul dari aktivitas transaksi ekonomi Yeager (1999 dalam Yustika, 2006).

Tabel 4. Biaya pengamanan kontrak pada Kelembagaan Pertanian Gapoktan Jaya Makmur Penerima Program PUAP

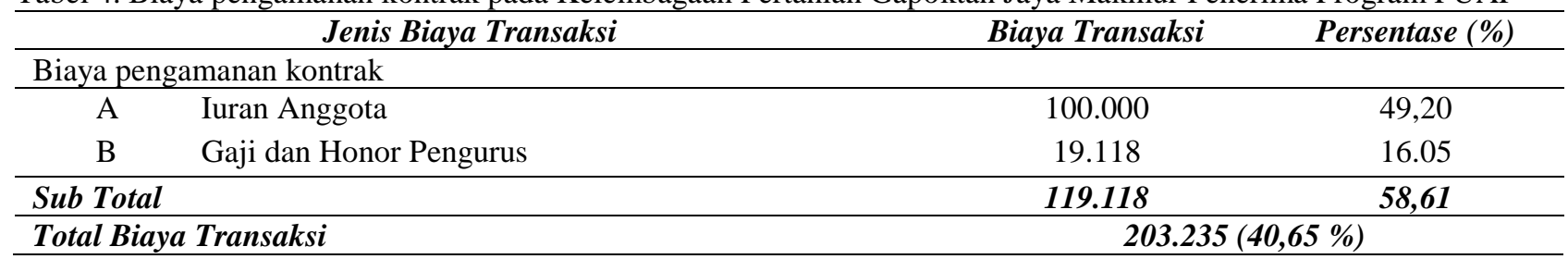

Sumber : Data Primer (diolah), 2017

Tabel 4 menunjukkan bahwa komponen biaya pengamanan kontrak terdiri dari iuran anggota, gaji dan honor pengurus, dan insentif. Biaya yang dikeluarkan anggota Gapoktan yang berupa iuran anggota yang dilaksanakan setiap musim tanam. Sehingga secara tidak langsung sudah mengurangi dana PUAP (Pengembangan Usaha Agribisnis Pedesaan) yang diterima petani (anggota Gapoktan). Untuk biaya pengamanan kontrak yang lain seperti honor pengurus Gapoktan, diberikan kepada ketua, sekretaris dan bendahara. Pemberian honor tersebut sudah disetujui oleh para anggota Gapoktan penerima program PUAP dengan tujuan untuk menganti waktu yang telah diluangkan pada saat mengurus program PUAP.

Biaya pengamanan kontrak didominasi oleh biaya iuran anggota sebesar Rp. 100.000,00 atau 49,20\% dari total biaya transaksi sebesar Rp. 203.235,00. Biaya iuran anggota dikeluarkan anggota Gapoktan yang merupakan kewajiban anggota Gapoktan, yang nantinya diperuntukan untuk anggota Gapoktan juga. Dalam proses pengajuan program PUAP, yang berperan adalah pengurus Gapoktan (ketua, sekretaris, dan bendahara). Pengurus Gapoktan melakukan pertemuan dengan anggota Gapoktan dan berkoordinasi dengan dinas terkait. Pengurus Gapoktan membutuhkan waktu dalam proses pengajuan program PUAP. Para pengurus Gapoktan merupakan petani sehingga pengurus sering kali meninggalkan pekerjaannya, oleh karena itu anggota Gapoktan menyetujui pemberian honor untuk pengurus Gapoktan. Besarnya gaji atau honor pengurus sebesar Rp. 19.118,00 atau 16,05 \% dari total biaya transaksi sebesar Rp. 203.235,00. Untuk biaya pengamanan kontrak yang paling sedikit adalah gaji atau honor pengurus. Dalam proses pengajuan program PUAP, Gapoktan memerlukan masukan dan arahan dari penyuluh setempat.

\section{KESIMPULAN DAN SARAN}

Rata-rata biaya transaksi per anggota dalam penerimaan Program PUAP sebesar Rp. 203.235,00. Biaya pengamanan kontrak merupakan jenis biaya transaksi yang terbesar jika dibandingkan dengan biaya informasi maupun biaya koordinasi yaitu sebesar 58,61 \%. Penyaluran dana Program PUAP kepada anggota sebesar Rp. 500.000, 00, setelah adanya biaya transaksi maka dana bantuan program PUAP yang diterima menjadi Rp. 296.765,00 atau 59,35 \%. Dengan adanya biaya transaksi maka dana batuan dari program PUAP yang diperoleh oleh anggota tanpa disadari berkurang. Biaya transaksi tersebut akan mengurangi bantuan modal petani yang didapatkan sehingga petani akan terkendala dalam berusahatani atau usaha. 
Berdasarkan penelitian yang telah dilakukan, maka saran yang dapat diberikan dalam penelitian ini adalah bagi Gapoktan, komponen biaya dalam pengajuan program PUAP sebaiknya disederhanakan atau dikurangi sehingga akan menekan biaya transaksi. Sedankan bagi pemerintah, dengan adanya kebijakan pemerintah yang berupa pemberikan insentif kepada petani yang berupa program PUAP harus memperhatikan prosedur penyalurannya dengan lebih dipersingkat atau mempergunakan sistem online.

\section{UCAPAN TERIMA KASIH}

Terima kasih disampaikan kepada Kemenristekdikti (Kementerian Riset, Teknologi, dan Pendidikan Tinggi) yang telah mendanai penelitian ini melalui Hibah Penelitian.

\section{DAFTAR PUSTAKA}

Akmal, 2006. Koordinasi Antar Instansi Terkait dalam Pelaksanaan Pembangunan di Daerah. Jurnal Demokrasi 5(1) : 1-12.

Allen, D.W. 2005. Marriage as an institution : A New Institutional Economic Approach. Simon Fraser University : Kanada.

Arifin, B. 2006. Transaction Cost Analysis of Upstream-Downstream Relations in Watershed Services : Lessons From Community-Based Forestry Management in Sumatera, Indonesia. Journal of International Agriculture 45(4) : 361-375.

Anggraeni, N.L.V., Muhammad, A.Z.M. dan Bambang, S.H. 2014. Peran dan Koordinasi Stakeholder dalam Pengembangan Kawasan Minapolitan di Keacamatan Nglegok Kabupaten Blitar. Jurnal Administrasi Publik 3(12) : 2070-2076.

Furubotn, E. G., and Rudolf R. 2005. Institutions and Economic Theory : The Contribution of the New Intitutional Economics. Second Edition. Ann Arbor : The University of Michigan Press.

United Nations Development Program (UNDP). 2013. Indek Pembangunan

Manusia.http://id.wikipedia.org/wiki/indeks pembangunan Manusia. [diakses 14 April 2016]

Mulyana, D. 2005. Ilmu Komunikasi : Suatu Pengatar. Remaja Rosdakarya. Bandung.

Nasrul, W. 2012. Pengembangan Kelembagaan Pertanian Untuk Peningkatan Kapasitas Petani terhadap Pembangunan Pertanian. Menara Ilmu 3(29) : 166-174.

Rintjap, A.K., 2015. Efektifitas Komunikasi dalam Penerimaan Informasi pada Kelompok Peternak Sapi Potong di Keacmatan Remhoken, Kabupaten Minahasa, Sulawesi Utara. J PROSEMNAS MASY BIODIV INDOV 1(7) : 1711-1714.

Rahman, A. 2011. Analisis Biaya Transaksi dan Pelaksanaan Pola Kemintraan Usaha Ayam Ras Pedaging di Kabupaten Maros (tesis). Program Studi Agribisnis. Universitas Hasanuddin. Makasar.

Sagala, Z. 2010. Dampak Program PUAP terhadap Pendapatan Petani (Skipsi). Bogor : Institut Pertanian Bogor.

Setiani, B. 2015. Prinsip-Prinsip Pokok Pengelolaan Jasa Transportasi Udara. Jurnal Ilmiah Widya 3(2) : 103-109.

Setyanti, A.M. 2016. Analisis Biaya Transaksi Kelembagaan Kelompok Tani di Indonesia. http://www.scribed.com/document/335393060/analisis-biaya-transaksi-kelembagaan-kelompoktani-docx [diakses 26 September 2017]. 
Sugiarto, D. Siagian, L.S. Sunarto, dan D.S. Oetomo. 2003. Teknik Sampling. Gramedia Pustaka Utama. Jakarta

Wijianto, A. A.N. Rachmawati, dan S. Marwanti. 2012. Pengaruh Program PUAP terhadap Produktivitas dan Pendapatan Usahatani Padi di Kabupaten Kalirejo.

Williamson, O.E., 1986. Economic Organization : Firms, Market and Policy Control. New York : New York University Press

Yustika, A. E., 2006. Ekonomi Kelembagaan : Definisi, Teori dan Aplikasi. Universitas Brawijaya. Malang. 2006.

Suciati, L.P., Bambang, J., Akhmad, F. \& Ernan, R. 2014. Peran Kelembagaan Perdesaan untuk Keberlanjutan Penerapan SRI diKabupaten Karawang. Jurnal Ekonomi dan Pembangunan Indonesia 14(2) : 109-126.

Suroso Y., 2012. Faktor-Faktor Dominan Yang Mempengaruhi Keberhasilan Pengembangan Usaha Agribisnis Pedesaan (PUAP) pada Usahatani padi Sawah dan jagung di Kab. Lampung Tengah (Tesis). Pascasarjana Fakultas Pertanian. Universitas Lampung.

Zulkarnain, Dwi H., Eka K., 2010. Keunggulan Komparatif dan Kompetitif dalam Produksi Padi di Kabupaten Lampung Tengah. Propinsi Lampung. Jurnal Pertanian Terapan 10(3) : 185-199. 